\title{
Knowledge, Attitude and Barriers of Practice Towards Integrated Counseling and Testing Centre among Antenatal Mothers Attending Antenatal Clinic at Selected Hospitals of Gangtok, Sikkim
}

\author{
Shadap A*, Pangambam S, Jayaswal S, Nath S, Pradhan M, Misao N, \\ Subba M, Sharma A, Chettri P, Subba P, Rai K, Chettri R, Bhattarai Z, \\ Poudyal R and Prasad R \\ Sikkim Manipal University, India
}

*Corresponding author: Arkierupaia Shadap, Sikkim Manipal

Tadong, Gangtok, Sikkim, India, Tel: 8436149397; Email: shadaparkierupaia@gmail.com

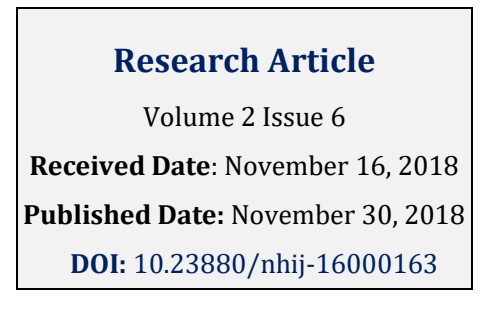

University, $\quad 5$ th $\quad$ Mile

\begin{abstract}
Introduction: Prevention of mother to child transmission aims at reducing the risk of the mother infecting her child with HIV. Comprehensive prevention of mother to child transmission programmes has nearly eliminated MTCT in developed countries. However, in settings with limited resource only $9 \%$ of all HIV positive pregnant women benefits from such services. ICTC plays an important role in Prevention of Mother Transmission to Child Transmission.
\end{abstract}

Aims of the Study: The aim of the study is to assess knowledge, attitude and determine the perceptive barriers of practices towards Integrated Counseling and Testing Centre among antenatal mother.

Materials and Methods: The study adopted quantitative approach and descriptive research design. The study sample included 100 antenatal mothers who attended antenatal clinic at Central Referral Hospital, Sikkim. A validated structured knowledge questionnaire, an attitude likert scale and semi structured barrier questionnaire was used for data collection. The sample selection was done using the non probability purposive sampling.

Results: The result of the study revealed that 65\% participant were having good knowledge, 28\% were having average knowledge and 7\% were having poor knowledge. $78 \%$ of participants were having favourable attitude and $22 \%$ were unfavourable attitude towards ICTC. There was also a positively moderate correlation between knowledge and attitude towards ICTC. $8 \%$ of the participants have refused to attend ICTC and 4\% said that ICTC should be removed from routine antenatal check up.

Conclusion: The study shows that majority of the participant were having good knowledge with favourable attitude towards ICTC. But still there is a need to increase the knowledge and attitude of the antenatal mothers through informational booklet.

Keywords: Knowledge; Attitude; Barriers; Practice; Integrated Counseling and Testing Centre; HIV/AIDS 


\section{Nursing \& Healthcare International Journal}

Abbreviations: HIV: Human Immunodeficiency Virus; AIDS: Acquired Immunodeficiency Syndrome; UNAIDS: United Nation Program on HIV/AIDS; NACO: National Aids Control Organization; ICTC: Integrated Counselling and Testing Centre's; VCT: Voluntary Counselling and Testing.

\section{Introduction}

Human immunodeficiency virus (HIV) is a retro virus that causes HIV infection and over time Acquired Immunodeficiency Syndrome (AIDS). HIV infects vital cells in the human immune system such as $\mathrm{T}$ cells. It gradually attacks the immune system which is our body natural defense against illness. The virus destroys a type of WBC called a T helper cell and make copies of itself inside them. AIDS is the final stage of HIV infection and not everyone who has HIV advances to this stage. Aids are the stage of infection that occurs when immune system is badly damaged. AIDS is defined in terms of either a $\mathrm{CD}^{4+} \mathrm{T}$ cells count below 200 cells or the occurrence of specific disease in association with HIV infection.HIV envelops AIDS within 10 years. The most common initial conditions that alert to the presence of AIDS are pneumocystis pneumonia, cachexia in the form of HIV wasting syndrome and esophageal candidiasis; other common signs include recurring respiratory tract infection [1].

Approximately $80 \%$ of HIV cases are transmitted sexually and further $10 \%$ perinatally or during breast feeding. Hence the health sector has looked to sexual and reproductive health programme for leadership and guidance in providing information and counselling to prevent transmission [2]. According to UNAIDS (United Nation Program on HIV/AIDS), approximately 36.9 million people worldwide are living with HIV/AIDS at the end of 2014. Of these 2.6 million are children less than 15 years old, 1.5 million pregnant women living with HIV were assessing antiretroviral therapy to avoid transmission of HIV to the children and new HIV infections among children were reduced by $58 \%$ from 2000 to 2014 [3]

According to UNAIDS Gap report 2016 India has the third largest epidemic in the world. About 2.1 million people living with HIV and 0.3 are among adults with $43 \%$ are on antiretroviral treatment. 86000 new HIV infections have found. In 2013, 35000 pregnant women were living with HIV and only 18\% received PMTCT (Prevention of Mother to Child Transmission) treatment. As a result 13000 children were born with HIV [4].
According to the National Aids Control Organization (NACO), Ministry of health and family welfare, Government of India, the Northeast States, though less populated as compared to other Indian states, still have some 100,000 people who live with HIV/AIDS in eight North-eastern states. Among Adult HIV and AIDS prevalence rates in Manipur and Nagaland are 1.57 anto reflected 1.2 respectively [5].

According to Sikkim State AIDS Control Society (SSACS) in Sikkim 361 people living with HIV/AIDS out of which 143 are males and 218 are females in the year 2015 [6].

Acquired immunodeficiency syndrome (AIDS) has emerged as one of the most serious public health problem in the country. Integrated counseling and testing centre's (ICTC) are key points for a wide range of interventions in HIV prevention and care. Voluntary counseling and testing (VCT) for HIV is the process by which an individual undergoes counseling to enable him or her to make an informed choice about being tested for HIV. According to the Joint United Nations program on HIV/AIDS (UNAIDS), VCT has a support and should be encouraged. VCT has thus become integral part of HIV prevention and care programs in many countries. Services have evolved to reflect developments in the treatment and care for HIV-related illness and with this, the recognition of VCT as important in reducing HIV transmission [7].

Sagili $\mathrm{H}$, et al. conducted a study on "Knowledge of HIV/AIDS and attitude towards voluntary counseling and testing among antenatal clinical attendees" reveals that the lack of adequate knowledge regarding HIV and preventive practices against mother to child transmission may be one of the reason for HIV transmission from mother to fetus [8].

\section{Materials and Methods}

\section{Research Approach}

Quantitative survey approach.

\section{Research Design}

Non- experimental descriptive survey design.

\section{Setting of the Study}

Antenatal clinic of Central Referral Hospital (CRH) Gangtok, East Sikkim. 


\section{Nursing \& Healthcare International Journal}

\section{Sample and Sampling Techniques}

- Sample size: 100 antenatal mothers attending antenatal clinic

- Sampling technique: Non probability Purposive sampling technique

- Sampling criteria

- Inclusion criteria: Antenatal mothers attended antenatal clinic of CRH and antenatal mother who were willing to participate in the study.

- The study was conducted after getting clearance from the Institutional Ethical Committee, Sikkim Manipal University and written consent from participants.

\section{Results and Discussion}

Analysis and interpretation of data were done in accordance to the objectives of the study using appropriate statistics. The collected data was organized and interpreted using descriptive and inferential statistics, coded and analyzed as per the objectives of the study under the following headings:

Section I: Table1 Frequency and percentage distribution of demographic variables.

\begin{tabular}{|c|c|c|}
\hline Demographic variables & Frequency & Percentage \\
\hline \multicolumn{3}{|c|}{ Age in years } \\
\hline $18-22$ & 18 & $18 \%$ \\
\hline $23-27$ & 26 & $26 \%$ \\
\hline$\geq 28$ & 56 & $56 \%$ \\
\hline \multicolumn{3}{|c|}{ Residence } \\
\hline Rural & 44 & $44 \%$ \\
\hline Urban & 56 & $56 \%$ \\
\hline \multicolumn{3}{|c|}{ Marital status } \\
\hline Married & 100 & $100 \%$ \\
\hline Unmarried & 0 & - \\
\hline \multicolumn{3}{|c|}{ Religion } \\
\hline Hindu & 66 & $66 \%$ \\
\hline Buddhist & 23 & $23 \%$ \\
\hline Christian & 10 & $10 \%$ \\
\hline Others & 1 & $1 \%$ \\
\hline \multicolumn{3}{|c|}{ Occupation } \\
\hline Private & 21 & $21 \%$ \\
\hline Govt. Employee & 13 & $13 \%$ \\
\hline Housewife & 66 & $66 \%$ \\
\hline \multicolumn{3}{|c|}{ Level of education } \\
\hline Illiterate & 2 & $2 \%$ \\
\hline Can read only & - & - \\
\hline Can read and write & 2 & $2 \%$ \\
\hline Primary school & 6 & $6 \%$ \\
\hline Middle school & 14 & $14 \%$ \\
\hline High school & 48 & $48 \%$ \\
\hline Graduate & 23 & $23 \%$ \\
\hline Post graduated & 5 & $5 \%$ \\
\hline \multicolumn{3}{|c|}{ Family monthly income } \\
\hline Less than 5000 & 8 & $8 \%$ \\
\hline $5001-10000$ & 36 & $36 \%$ \\
\hline $10001-15000$ & 31 & $31 \%$ \\
\hline$>15000$ & 26 & $26 \%$ \\
\hline \multicolumn{3}{|c|}{ Gravida } \\
\hline Primi & 49 & $49 \%$ \\
\hline
\end{tabular}

Shadap A. Knowledge, Attitude and Barriers of Practice Towards Integrated Counseling and Testing Centre among Antenatal Mothers Attending Antenatal Clinic at Selected 


\section{Nursing \& Healthcare International Journal}

\begin{tabular}{|c|c|c|}
\hline Multi & 51 & $51 \%$ \\
\hline \multicolumn{3}{|c|}{ Heard about HIV/AIDS } \\
\hline a) Yes & 96 & $96 \%$ \\
\hline b) No & 4 & $4 \%$ \\
\hline \multicolumn{3}{|c|}{ If yes, What was Source of information? } \\
\hline i) Friends & 44 & $44 \%$ \\
\hline ii) Health care professionals & 20 & $20 \%$ \\
\hline iii) Family members and relatives & 6 & $6 \%$ \\
\hline iv) Mass media & 24 & $24 \%$ \\
\hline \multicolumn{3}{|c|}{ Have you heard about ICTC } \\
\hline \multicolumn{3}{|c|}{ (Integrated Counselling and Testing Centre) } \\
\hline a) Yes & 88 & $88 \%$ \\
\hline b) No & 12 & $12 \%$ \\
\hline \multicolumn{3}{|c|}{ If yes, What was the source of information? } \\
\hline i) Health professionals & 73 & $83 \%$ \\
\hline ii) Family members/ relatives & 6 & $6 \%$ \\
\hline iii) Friends & 5 & $5 \%$ \\
\hline iv) Mass media & 4 & $4 \%$ \\
\hline
\end{tabular}

Table 1: Frequency and percentage of distribution of demographic variables [N=100].

Section II: Table 2 Frequency and percentage distribution of knowledge score towards ICTC.

\begin{tabular}{|c|c|c|}
\hline Knowledge score & Frequency & Percentage \\
\hline Good Knowledge & 65 & $65 \%$ \\
\hline Average Knowledge & 28 & $28 \%$ \\
\hline Poor Knowledge & 7 & $7 \%$ \\
\hline
\end{tabular}

Table 2: Frequency and percentage distribution of knowledge score towards ICTC [N=100].

Section III: Table 3 Frequency and percentage of distribution of attitude towards ICTC.

\begin{tabular}{|c|c|c|}
\hline Attitude score & Frequency & Percentage \\
\hline Favourable attitude & 78 & $78 \%$ \\
\hline Unfavourable attitude & 22 & $22 \%$ \\
\hline
\end{tabular}

Table 3: Frequency and percentage distribution of attitude towards ICTC and HIV/AIDS [N=100].

Section IV: Table 4 Correlation between knowledge and attitude towards ICTC.

\begin{tabular}{|c|}
\hline Karl Pearson's Correlation Coefficient \\
\hline $\mathrm{r}=\sum(\mathrm{x}-\mathrm{x})(\mathrm{Y}-\mathrm{Y}) / \sqrt{ } \sum(\mathrm{x}-\mathrm{x})^{2}(\mathrm{Y}-\mathrm{Y})^{2}$ \\
\hline $\mathrm{r}=0.63$ \\
\hline
\end{tabular}

The finding in the Table 4 shows that there is a positively moderate correlation between knowledge and attitude towards ICTC.

Section V: Tables 5 \& 6 Association between knowledge and attitude with selected demographic variables. 


\section{Nursing \& Healthcare International Journal}

\begin{tabular}{|c|c|c|c|c|c|c|}
\hline \multirow{2}{*}{ Demographic variables } & \multicolumn{2}{|c|}{ Median } & \multirow{2}{*}{ df } & \multirow{2}{*}{$\mathbf{X}^{2}$} & \multirow{2}{*}{ Table value } & \multirow{2}{*}{ Remarks } \\
\hline & $<23$ & $\geq 23$ & & & & \\
\hline \multicolumn{7}{|c|}{ Age in years } \\
\hline $18-22$ & 8 & 9 & \multirow{3}{*}{2} & \multirow{3}{*}{0.29} & \multirow{3}{*}{5.99} & \multirow{3}{*}{ Non-significant } \\
\hline $23-27$ & 14 & 12 & & & & \\
\hline$\geq 28$ & 24 & 33 & & & & \\
\hline \multicolumn{7}{|c|}{ Residence } \\
\hline Rural & 20 & 24 & \multirow{2}{*}{1} & \multirow{2}{*}{0.0095} & \multirow{2}{*}{3.84} & \multirow{2}{*}{ Non-significant } \\
\hline Urban & 26 & 30 & & & & \\
\hline \multicolumn{7}{|c|}{ Marital status } \\
\hline Married & 46 & 54 & - & \multirow{2}{*}{-} & \multirow{2}{*}{ - } & \multirow{2}{*}{ Not- applicable } \\
\hline Unmarried & 0 & 0 & - & & & \\
\hline \multicolumn{7}{|c|}{ Religion } \\
\hline Hindu & 28 & 39 & \multirow{4}{*}{3} & \multirow{4}{*}{31.01} & \multirow{4}{*}{7.82} & \multirow{4}{*}{ Significant } \\
\hline Buddhist & 8 & 14 & & & & \\
\hline Christian & 8 & 2 & & & & \\
\hline Others & 1 & 0 & & & & \\
\hline \multicolumn{7}{|c|}{ Occupation } \\
\hline Private & 10 & 11 & \multirow{3}{*}{2} & \multirow{3}{*}{3.45} & \multirow{3}{*}{5.99} & \multirow{3}{*}{ Non-significant } \\
\hline Govt. Employee & 2 & 11 & & & & \\
\hline Housewife & 33 & 33 & & & & \\
\hline \multicolumn{7}{|c|}{ Level of education } \\
\hline Illiterate & 2 & 0 & & & & \\
\hline Can read and write & 2 & 0 & & & & \\
\hline Primary school & 4 & 2 & & & & \\
\hline Middle school & 8 & 6 & - & - & - & Not- applicable \\
\hline High school & 21 & 27 & & & & \\
\hline Graduate & 8 & 15 & & & & \\
\hline Post graduated & 1 & 4 & & & & \\
\hline
\end{tabular}

Family monthly income

\begin{tabular}{|c|c|c|c|c|c|c|}
\hline Less than 5000 & 4 & 4 & \multirow{4}{*}{3} & \multirow{4}{*}{2.57} & \multirow{4}{*}{7.82} & \multirow{4}{*}{ Non-significant } \\
\hline $5001-10000$ & 17 & 18 & & & & \\
\hline $10001-15000$ & 18 & 14 & & & & \\
\hline$>15000$ & 7 & 18 & & & & \\
\hline \multicolumn{7}{|c|}{ Gravida } \\
\hline Primi & 23 & 26 & \multirow{2}{*}{1} & \multirow{2}{*}{0.145} & \multirow{2}{*}{3.84} & \multirow{2}{*}{ Non-significant } \\
\hline Multi & 24 & 27 & & & & \\
\hline
\end{tabular}

Table 5: Association between knowledge with selected demographic variables [ $\mathrm{N}=100]$. 
Nursing \& Healthcare International Journal

\begin{tabular}{|c|c|c|c|c|c|c|}
\hline \multirow{2}{*}{ Demographic variables } & \multicolumn{2}{|c|}{ Median } & \multirow{2}{*}{ df } & \multirow{2}{*}{$\mathbf{X}^{2}$} & \multirow{2}{*}{ Table value } & \multirow{2}{*}{ Remarks } \\
\hline & $<50$ & $\geq 50$ & & & & \\
\hline \multicolumn{7}{|c|}{ Age in years } \\
\hline $18-22$ & 5 & 13 & \multirow{3}{*}{2} & \multirow{3}{*}{6.26} & \multirow{3}{*}{5.99} & \multirow{3}{*}{ Significant } \\
\hline $23-27$ & 7 & 19 & & & & \\
\hline$\geq 28$ & 11 & 45 & & & & \\
\hline \multicolumn{7}{|c|}{ Residence } \\
\hline Rural & 10 & 34 & \multirow{2}{*}{1} & \multirow{2}{*}{0.024} & \multirow{2}{*}{3.84} & \multirow{2}{*}{ Non-significant } \\
\hline Urban & 12 & 44 & & & & \\
\hline \multicolumn{7}{|c|}{ Marital status } \\
\hline Married & 22 & 78 & \multirow{2}{*}{-} & \multirow{2}{*}{-} & \multirow{2}{*}{-} & \multirow{2}{*}{ Not- applicable } \\
\hline Unmarried & 0 & 0 & & & & \\
\hline \multicolumn{7}{|c|}{ Religion } \\
\hline Hindu & 12 & 54 & \multirow{4}{*}{-} & \multirow{4}{*}{ - } & \multirow{4}{*}{ - } & \multirow{4}{*}{ Not- applicable } \\
\hline Buddhist & 6 & 18 & & & & \\
\hline Christian & 4 & 5 & & & & \\
\hline Others & 0 & 1 & & & & \\
\hline \multicolumn{7}{|c|}{ Occupation } \\
\hline Private & 10 & 11 & & & & \\
\hline Govt. Employee & 2 & 11 & 2 & 14.51 & 5.99 & Significant \\
\hline Housewife & 33 & 33 & & & & \\
\hline & & evel c & fed & cation & & \\
\hline Illiterate & 2 & 0 & & & & \\
\hline Can read and write & 2 & 0 & & & & \\
\hline Primary school & 4 & 2 & & & & \\
\hline Middle school & 8 & 6 & - & - & - & Not- applicable \\
\hline High school & 21 & 27 & & & & \\
\hline Graduate & 8 & 15 & & & & \\
\hline Post graduated & 1 & 4 & & & & \\
\hline & Fan & ily $\mathrm{m}$ & nth & incon & & \\
\hline Less than 5000 & 1 & 7 & & & & \\
\hline $5001-10000$ & 7 & 29 & 2 & 1025 & 782 & Sianificant \\
\hline $10001-15000$ & 12 & 19 & 3 & 10.05 & 1.02 & Sigmintedit \\
\hline$>15000$ & 2 & 23 & & & & \\
\hline & & & avic & & & \\
\hline Primi & 12 & 36 & 1 & 015 & $384+2>$ & Non_cionificant \\
\hline Multi & 10 & 42 & 1 & 0.15 & 3.84 & Non-signimicant \\
\hline
\end{tabular}

Table 6: Association between attitude with selected demographic variables [ $\mathrm{N}=100]$. 


\section{Nursing \& Healthcare International Journal}

\section{Discussion}

The findings of the present study reveals that $65 \%$ participant were having good knowledge, 28\% were having average knowledge and $7 \%$ were having poor knowledge which is supported by a study conducted by Priyanka Kapoor, et al. among attendees of Integrated Counseling and Testing Centre at SMS Medical College, Jaipur which shows that out of 177participants, $77.9 \%$ had good knowledge about HIV/AIDS [9]. 78\% have favourable attitude towards ICTC which is supported by the study findings of VN Addo which shows out of 334 $90 \%$ has positive attitude towards attending VCT [10]. Present study also shows that $8 \%$ of participants wanted to refuse attending ICTC giving the reasons that it is unnecessary, unwillingness, fear of negligence, fear of being at risk and time consuming, whereas, Haily DT, et al. in their study reveals that $25 \%$ people want to attend VCT and others have a stigmization towards it [11].

\section{Conclusion}

There is a need to improve knowledge about HIV/AIDS and importance of attending ICTC as well as the attitude towards attending ICTC. The health care professionals have to take initiatives and improve the knowledge through various methods. It is known that prevention of an infection is more important, therefore awareness of the various aspects of this disease deserves the ultimate importance from the strategic point of view.

\section{Acknowledgement}

The investigators would like to thank Principal, Sikkim Manipal College of Nursing and the participants for which without them the study would not have been a successful one.

\section{References}

1. HIV/AIDS.

2. Askew J, Berer M (2011) Contribution to sexual and reproductive health. International journal of gynaecology and obstetrics.

3. Global HIV/AIDS statistic.

4. National HIV/AIDS Statistics.

5. Northeast HIV/AIDS statistics.

6. Sikkim State AIDS Control Society (SSACS) (2015).

7. (2008) Joint United Nations Programme on HIV/AIDS (UNAIDS) Reports on the global Aids epidemic.

8. Sagili H, Kumar S, Lakshminarayanan S, Papa D, Abi C (2015) Knowledge of HIV/AIDS and attitude towards voluntary counseling and testing. Among Antenatal Clinic Attendees at a Tertiary Care Hospital in India. The journal of Obstetrics and Gynaecology 65(2): 104-110.

9. Priyanka K, Manoj VK (2015) A cross sectional study of knowledge assessment regarding HIV/AIDS. International journal of prevention, curative and community medicine Medical and Social Health 1(3).

10. Addo VN (2005) Pregnant women's knowledge of and attitudes to HIV testing. Ghana Medical Journal 39(2): 50-54.

11. Teklehaimanot HD, Teklehaimanot A, Yohannes M, Biratu D (2016) Factor influencing the uptake of voluntary HIV counselling and testing. BMC Public Health 16: 239. 